http://jmscr.igmpublication.org/home/ ISSN (e)-2347-176x ISSN (p) 2455-0450 crossref DOI: https://dx.doi.org/10.18535/jmscr/v9i1.11

\title{
Importance of Microalbuminuria in Essential Hypertension
}

\author{
Authors \\ Dr N M Sampath Anil Kumar ${ }^{1}$, Dr. Satya Kumar $\mathbf{K}^{2^{*}}$, Dr Krishna Mythili Sreeram², \\ Dr Jami Suneel ${ }^{4}$, Dr M Raja Sekhar Reddy ${ }^{5}$ \\ ${ }^{1,3,4,5}$ Post Graduate student, Department of General Medicine, Maharajah's Institute of Medical Sciences, \\ Nellimarla, Vizianagaram, Andhra Pradesh, India \\ ${ }^{2}$ Assistant Professor, Department of General Medicine, Maharajah's Institute of Medical Sciences, \\ Nellimarla, Vizianagaram, Andhra Pradesh, India \\ *Corresponding Author \\ Dr Satya Kumar K.
}

\begin{abstract}
Background: Today, hypertension is the most critical public health problem. If left untreated, it increases coronary stroke events, heart failure, and renal failure ${ }^{1}$.Microalbuminuria in cases with established essential hypertension is a predictor of a higher risk of cardiovascular and renal dysfunction ${ }^{2}$. Early detection of microalbuminuria will help us to control the development of complications of hypertension with specific therapy for microalbuminuria.

Aims \& Objectives: To determine the prevalence of microalbuminuria in patients with primary hypertension and to study the correlation of microalbuminuria with clinical profile and complications of primary hypertension.

Materials and Methods: The study was conducted in Maharajah's institute of Medical sciences (MIMS) Nellimarla, from March 2019 to February 2020, included 100 patients.

Conclusion: Microalbuminuria in essential hypertension does not show any correlation with the sex of the patient. As the severity of hypertension increases, the degree of microalbuminuria also increases. An increase in systolic blood pressure has a better correlation with microalbuminuria than diastolic blood pressure. All patients with essential hypertension and microalbuminuria had retinopathy which showed as higher is the microalbuminuria, severe is the grade of retinopathy.

Keywords: Hypertension, Microalbuminuria, Joint National Committee VIII, Left ventricular hypertrophy, Retinopathy.
\end{abstract}

\section{Introduction}

- Today hypertension is the most critical public health problem. If left untreated, it increases coronary stroke events, heart failure, and renal failure. ${ }^{1}$

- There are variations in the prevalence of microalbuminuria between $10 \%$ to $40 \%$ reported in different studies.
- Microalbuminuria in cases with established essential hypertension is a predictor of a higher risk of cardiovascular and renal dysfunction. ${ }^{2}$

- Early detection of microalbuminuria will help us control the development of complications of hypertension with specific therapy for microalbuminuria. 
- The study was conducted to know the prevalence of microalbuminuria in patients with essential hypertension and to study the correlation of microalbuminuria with clinical profile and complications of primary hypertension

\section{Objectives}

1) To determine the prevalence of microalbuminuria in patients with primary hypertension.

2) To study the correlation of microalbuminuria with clinical profile and complications of primary hypertension.

\section{Material and Methods}

- The study was conducted in Maharajah's institute of Medical sciences (MIMS) Nellimarla, from March 2019 to February 2020, included 100 patients.

- Essential hypertension was diagnosed. The severity of hypertension has been classified as per the joint national committee (JNC) VIII. ${ }^{3}$

- In newly detected hypertensive patients, the diagnosis was based on the average of 2 or more BP readings taken at each of 2 or more visits after an initial screening.

Inclusion Criteria: Patient with essential hypertension admitted in medical wards of MIMS Hospital

\section{Exclusion Criteria}

- Patients with diabetes mellitus.

- Patients with secondary hypertension.

- Pregnancy-induced hypertension

- Twenty-four hours of urine for microalbuminuria estimation was done by Immune Turbidmetric assay.

- Ischemia heart disease (IHD) was diagnosed based on history and ECG changes indicative of Ischemia, Infarction, Cardiacdysrhythmia (or arrhythmia) . The chest X-ray is done to see cardiomegaly.

- Left ventricular hypertrophy (LVH) was diagnosed using the Sokolow Lyon Voltage criteria on ECG and confirmed by echocardiographic screening.

- Fundus examination is done, and retinopathy was classified as per KeithWagener- Barker (KWB) classification.

Characteristics of the study:

\begin{tabular}{|l|c|}
\hline PARAMETERS & STUDY GROUP \\
\hline AGE(YEARS) & $56.7 \pm 11.6$ \\
\hline $\begin{array}{l}\text { DURATION OF PRIMARY } \\
\text { HYPERTENSION }\end{array}$ & $7.5 \pm 5.2$ \\
\hline SYSTOLIC BP(mmHg) & $159.2 \pm 24.7$ \\
\hline DIASTOLIC BP(mmhg) & $96.86 \pm 14.3$ \\
\hline FBS(mg/dl) & $99.68 \pm 8.5$ \\
\hline SERUM CREATININE(mg/dl) & $1.03 \pm 0.03$ \\
\hline TOTAL CHOLESTEROL(mg/dl) & $193.8 \pm 25.6$ \\
\hline
\end{tabular}

\section{Results}

1) Prevalence of microalbuminuria in hypertension individuals

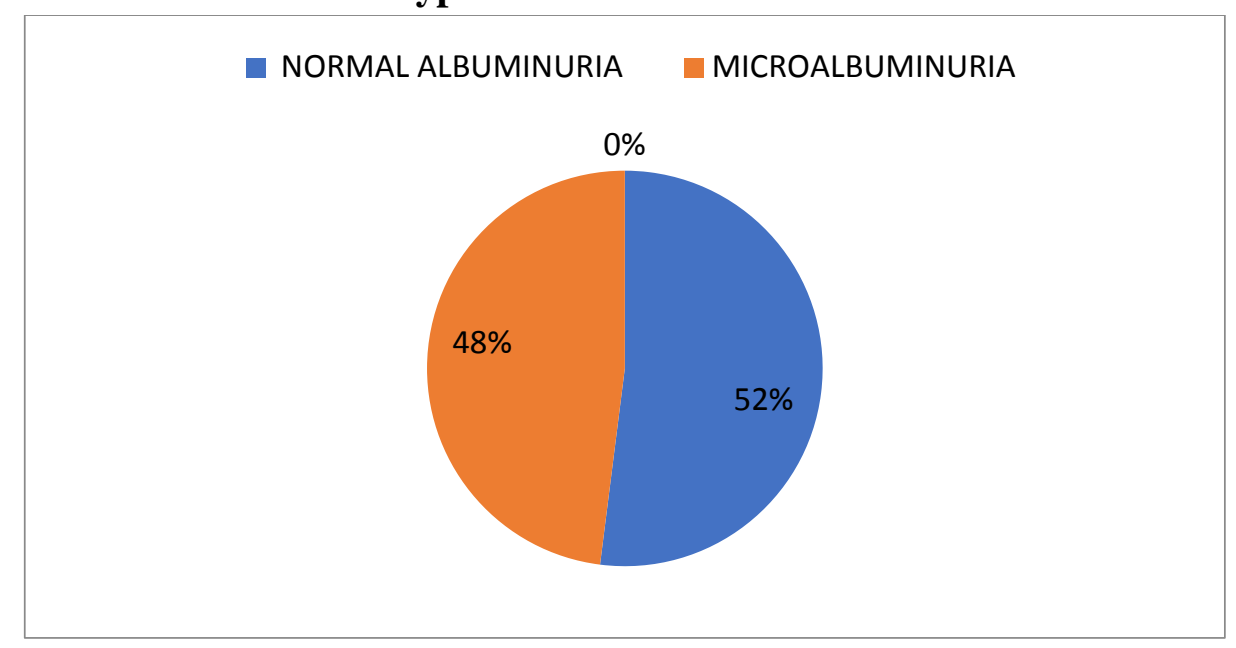


2) Albuminuria and Sex Distribution $p=0.594$ (Non-Significant)

\begin{tabular}{|l|c|c|c|}
\hline SEX & MICRO-ALBUMINURIA & NORMOALBUMINURIA & TOTAL \\
\hline MALE & $32(50 \%)$ & $32(50 \%)$ & 64 \\
\hline FEMALE & $16(44.4 \%)$ & $20(55.6 \%)$ & 36 \\
\hline TOTAL & 48 & 52 & 100 \\
\hline
\end{tabular}

3)Distribution of cases related to the severity of hypertension and Albuminuria ( $p=0.001)$ (significant)

\begin{tabular}{|c|c|c|c|}
\hline $\begin{array}{lr}\text { SEVERITY OF } \\
\text { HYPERTENSION }\end{array}$ & $\begin{array}{l}\text { MICRO-ALBUMINURIA } \\
\text { NO OF CASES }(\%) \\
\text { MEAN RANGE OF MICRO- } \\
\text { ALBUMINURIA }\end{array}$ & $\begin{array}{c}\text { NORMO-ALBUMINURIA } \\
\text { NO OF CASES } \\
\text { MEAN RANGE OF NORMO- } \\
\text { ALBUMINURIA }\end{array}$ & TOTAL \\
\hline STAGE 1 & $\begin{array}{c}16 \\
(29.62 \%) \\
72.19 \pm 36.48 \mathrm{mg} / \mathrm{dl}\end{array}$ & $\begin{array}{c}38 \\
(70.37 \%) \\
19.64 \pm 6.15 \mathrm{mg} / \mathrm{dl}\end{array}$ & 54 \\
\hline STAGE2 & $\begin{array}{c}32(69.5 \%) \\
132.1 \pm 92.6 \\
\end{array}$ & $\begin{array}{l}14(30.43 \%) \\
17.89 \pm 5.99\end{array}$ & 46 \\
\hline TOTAL & 48 & 52 & 100 \\
\hline
\end{tabular}

4) Distribution of cases related to the duration of hypertension and Albuminuria $(p=0.001)$ (significant)

\begin{tabular}{|l|c|c|c|}
\hline DURATION(YEARS) & MICRO-ALBUMINURIA & NORMO-ALBUMINURIA & TOTAL \\
\hline Less than $10 \mathrm{yrs}$ & $25(32.5 \%)$ & $52(67.5 \%)$ & 77 \\
\hline More than $10 \mathrm{yrs}$ & $23(100 \%)$ & 0 & 23 \\
\hline TOTAL & 48 & 52 & 100 \\
\hline
\end{tabular}

5) Grades of Retinopathy related to Albuminuria- $p=0.001$ (Significant)

\begin{tabular}{|l|c|c|c|}
\hline $\begin{array}{l}\text { GRADES OF } \\
\text { RETINOPATHY }\end{array}$ & MOCRO-ALBUMINURIA & NORMO-ALBUMINURIA & TOTAL \\
\hline NORMAL & 0 & $34(100 \%)$ & 34 \\
\hline I & $15(46.88 \%)$ & $17(53.12 \%)$ & 32 \\
\hline II & $24(96 \%)$ & $1(4 \%)$ & 25 \\
\hline III & $7(100 \%)$ & 0 & 7 \\
\hline IV & $2(100 \%)$ & 0 & 2 \\
\hline TOTAL & 48 & 52 & 100 \\
\hline
\end{tabular}

6) LV H on ECHO related to Albuminuria - $p=0.001$ (Significant)

\begin{tabular}{|l|c|c|c|}
\hline PARAMETERS & MICRO-ALBUMINURIA & NORMO-ALBUMINURIA & TOTAL \\
\hline NO LVH & $6(11.76 \%)$ & $45(88.24 \%)$ & 51 \\
\hline LVH + & $42(85.7 \%)$ & $7(14.3 \%)$ & 49 \\
\hline TOTAL & 48 & 52 & 100 \\
\hline
\end{tabular}

7) Albuminuria related to ischemic heart disease(IHD) $p=0.001$ (significant)

\begin{tabular}{|l|c|c|c|}
\hline PARAMETERS & MICRO-ALBUMINURIA & NORMO-ALBUMINURIA & TOTAL \\
\hline NO H/O IHD & $33(42.86 \%)$ & $44(57.14 \%)$ & 77 \\
\hline WITH H/O IHD & $15(65.22 \%)$ & $8(34.78 \%)$ & 23 \\
\hline TOTAL & 48 & 52 & 100 \\
\hline
\end{tabular}

8) Albuminuria related to the history of stroke / TIA- $p=0.001$ ( significant)

\begin{tabular}{|l|c|c|c|}
\hline PARAMETERS & MICRO-ALBUMINURIA & NORMO-ALBUMINURIA & TOTAL \\
\hline NO H/O STROKE & $31(38.7 \%)$ & $49(61.2 \%)$ & 80 \\
\hline WITH H/O STROKE & $17(85 \%)$ & $3(15 \%)$ & 20 \\
\hline TOTAL & 48 & 52 & 100 \\
\hline
\end{tabular}




\section{Discussion}

- Several retrospective and cross-sectional studies reported that cardiovascular disease prevalence is significantly higher among hypertensive patients with microalbuminuria than hypertensive cases without microalbuminuria. ${ }^{4,5,6}$

- Microalbuminuria in the present study was slightly higher than the other studies.

- Therefore, microalbuminuria's finding should trigger a careful search for other cardiovascular risk factors and evidence of end-organ damage. ${ }^{5}$

- Whether microalbuminuria can predict the risk of progressive renal disease in patients with essential hypertension is not clear. ${ }^{6}$

\section{Conclusion}

- In the present study, the prevalence of microalbuminuria in primary hypertension was found to be $48 \%$.

- Microalbuminuria in essential hypertension does not show any correlation with the sex of the patient.

- As the severity of hypertension increases, the degree of microalbuminuria also increases.

- An increase in systolic blood pressure has a better correlation with microalbuminuria than diastolic blood pressure.

- All patients with essential hypertension and microalbuminuria had retinopathy which showed as higher is the microalbuminuria, severe is the grade of retinopathy.

- In patients of essential hypertension with microalbuminuria, $85 \%$ had LVH, $65 \%$ had IHD, $85 \%$ had cerebrovascular disease.

Keywords: Hypertension, Microalbuminuria, Joint National Committee VIII, Left ventricular hypertrophy, Retinopathy.

\section{Bibliography}

1. Maura Ravera, ElenaRatto, Simone Vettoretti, Francesca Viazzi, Giovanna Leoncini. Microalbuminuria and subclinical cerebrovascular damage in essential hypertension. J Nephrol 2002; 15: 519-524.

2. R Ghai, NP Singh Verma, A Goel, MK Bhatnagar, Prerna Kapoor, A Vashista. Microalbuminuria in NIDDM and essential hypertension - a marker of severe disease. JAPI 1994.

3. Aram V Chobanian, George L, Henry R, William C, Lee A, Joseph L., et al. Eight report of the Joint National Committee on prevention, detection. Evaluation and treatment of high blood pressure. JAMA 2014; 289(19).

4. Bigazzi R, Binachi S, Campese V, Baldari G. Prevalence of Microalbuminuria in a large population of patients with mild to moderate essential hypertension. Nephron 1992; 61 : 94-97.

5. Devereux RB, Reichek N. Echocardiographic determination of $\mathrm{LV}$ mass in man: anatomic validation of the method circulation 1977: 55: 613.

6. Kumar D, Arora P, Singh G. GMC / GND the hospital Amritsar: Prevalence of proteinuria in mild to moderate essential hypertension, A study of 200 patients: Japivol 49, Jan 2001. 